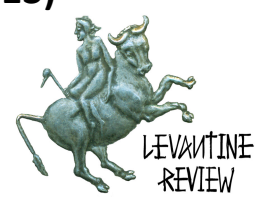

\title{
ARABIC-KARSHUNI: \\ AN ATTEMPT TO PRESERVE MARONITE IDENTITY; THE CASE OF ALEPPO
}

\author{
Francisco del Río Sánchez*
}

\begin{abstract}
This paper investigates the reasons behind Middle Eastern Syriac Christian communitiesparticularly the Maronites'-use of the Syriac script when writing Arabic; a phenomenon known as Karshuni.
\end{abstract}

Why do certain communities, such as the Jews or Syrian Christians, reject the adoption of the Arabic alphabet? Why do they prefer to preserve their own "national" scripts when writing in Arabic? If we assume that scripts or writing systems are linguistic codes characterized by artificiality with respect to spoken languages, we must then consider a doubly conscious artificiality in the case of Syrian Christians writing Arabic in Syriac script; a phenomenon which can be adequately explained only through the lens of sociological, religious and cultural patterns.

In these pages I will investigate the reasons why the Syriac Christian communities of the Near East, particularly the Maronites, have retained a peculiar way of writing Arabic, commonly known as Garshuni or, Karshuni, which is a graphic system characterized by the use of Syriac alphabet adapted to that purpose. I will present some conclusions using data collected from the libraries of northern Syria and Lebanon, and particularly from the collection of manuscripts preserved in the Maronite Mutraniyya (Metropolitan See) of Aleppo ${ }^{1}$. I will not deal with some aspects of Karshuni, which have already been studied by other scholars, such as the unresolved problem surrounding the etymology of the term Garshuni-Karshuni, ${ }^{2}$ or the orthography description of the graphic system known under this name ${ }^{3}$.

1. The results appear in three works: Francisco del Río, Catalogue des Manuscrits de la Fondation Georges et Mathilde Salem (Alep, Syrie) (Wiesbaden: Reichert Verlag 2008); Idem, Manuscrits syriaques conservés dans la bibliothèque des Maronites d'Alep (Syrie) (Piscataway NJ: Gorgias 2008); and Manuscrits en Arabe Karshuni conservés dans la bibliothèque des Maronites d'Alep, Syrie (Piscataway NJ: Gorgias 2010).

2. About the origin and the etymology of the term, consult Juan Pedro Monferrer, "Avantpropos" in Del Río, Manuscrits en Arabe Karshuni, v-ii.

3. A description of the orthographic conventions of Karshuni and their rapport with the Arabic writing system in Alessandro Mengozzi, "The History of Garshuni as a Writing System: Evidence from the Rabbula Codex" in Frederick Mario Fales and Julia Francesca 


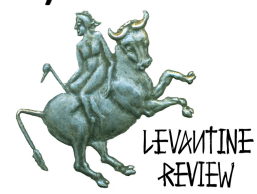

The dialectal expression btahki karshuni? ("are you speaking Karshuni?") can still be heard today in Lebanon and Syria. This Levantine slang is often used to express bewilderment when faced with unintelligible speech (equivalent to the English phrase "It's all Greek to me.") Yet the word "Karshuni" does not designate a language per se but rather a way of writing, in which case one would do well speaking of "Arabic Karshuni," "Ottoman" and "modern Turkish Karshuni" (e.g., the famous newspaper Lshono d-umto, published in Lebanon between 1927 and 1934,) "Persian Karshuni," "Kurdish Karshuni," and in non-Muslim contexts, "Armenian" and even "Malayalam Karshuni." 4 Usually the adjective "Karshuni" refers to Arabic texts written in Syriac characters, but it is in fact in Arabic proper that we find the most abundant testimonies about Karshuni.

The practice of writing Arabic-Karshuni, being a less well-known phenomenon than Judeo-Arabic (that is to say, Arabic written in Hebrew letters,) was not uncommon among Christians of Syriac tradition. In fact, there is a significant corpus of Karshuni books in Near-Eastern Christian libraries, and this amount increases as researchers begin discovering and uncovering the contents of uncatalogued collections. It is true that there is still much to excavate and parse in and about Karshuni; however, there are some certain data.

This study is based on careful examination of materials perserved in one of the major production centers of Karshuni texts, the Maronite Mutraniyya of Aleppo. In this northwestern Syrian town, the presence of an Arabized Maronite community goes back to the Middle Ages, ${ }^{5}$ even though a fully organized Diocese would not come into being until the beginning of the seventeenth century. ${ }^{6}$ In this sense, the existence of a Maronite

Grassi (eds.), CAMSEMUD 2007, Proceedings of the 13th Italian Meeting of Afro-Asiatic Linguistics (Padova: SARGON Editrice), 299-301.

4. See the bibliography proposed by Mengozzi, "The History of Garshuni", 297, n. 2. 5. In fact, all the Maronite manuscripts of Aleppo copied in this city show an entirely arabized community, and this can be verified by checking the language of the colophons (all of them are in Arabic or Arabic Karshuni with the exception of about 10 copies with end notes in Syriac or Armenian), and looking over the proper names and nisba (surname) of book owners and copyists; those of them related in their origins to Aleppo Maronites are all in Arabic. In the Ottoman period the Maronites of Aleppo had abandoned Syriac in favour of Arabic as their vernacular and had assimilated much of the Arabic culture as their own. It should be noted that This arabization clearly precedes the "cultural Arabism" stimulated during seventeenth and eighteenth centuries by Latin missionaries and Uniate churches of Syria as a concession to localist sentiments in order to make the spreading of the new dogma easier. Bruce Masters, Christians and Jews in the Ottoman Arab Word, the Roots of sectarism, (Cambridge: Cambridge Univ. Press 2001), $43,112$.

6. About the origin of the organization of this Maronite community and the causes of the massive migration of inhabitants of Mount Lebanon to the North of Syria during the last years of the Mamelukes, see Kemal Suleyman Salibi, Maronite historians of medieval Lebanon (Beirut: American University 1959), 51; Mariam de Ghantuz, I maroniti 


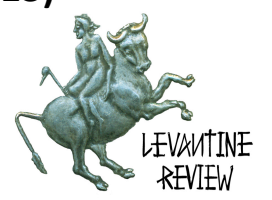

Library is directly related to the presence of a Resident Bishop of this ta'ifa (religious faction) in the city (that is, in the year 1634,) and the inauguration of a Mutraniyya near the old church of Mar Iliyas in the Jdeydeh quarter. ${ }^{7}$

The library of this community is a typical ecclesiastical collection, similar in form and content to others preserved elsewhere among the city's different Christian denominations. The library contains 1,640 manuscripts, most of which are written in Arabic (1,256 copies): only 134 copies are written in Syriac (less than one percent of the entire collection,) and 250 copies are in Arabic-Karshuni (about a six percent of the total holdings.) The oldest copies in this collection date back to the fifteenth century, and the most recent to the twentieth century. About ninety percent of the books were written in Aleppo, by local Maronite copyists. Some copies (about eight percent) came from Mount Lebanon (especially those dating back to the fifteenth and sixteenth centuries,) and from the Euphrates and Jazeera (about two percent total.) ${ }^{8}$ It should be emphasized that almost all these books can be placed in the Ottoman period (1516-1918,) a time in which the Maronites of Aleppo finalized the process of liturgical Arabization of local rituals. In this context, we can assert that:

1) The Arabic-Karshuni is a system pensé en arabe: in other words, it is Arabic "disguised as Syriac"; a text that is Syriac in appearance, but one preserving all the grammatical and orthographic standards of Arabic. ${ }^{9}$

2) This fact shows two realities: writing in Arabic-Karshuni requires a high command of Arabic grammar. On the other hand, it also shows that it is not necessary to have a good knowledge of Syriac in order to produce a text of these characteristics. It is sufficient to know the alphabet and the calligraphic rules governing the correct drawing of Syriac graphemes.

3) From a formal point of view, these Karshuni texts are deliberately designed to look like Syriac books. The development of this style of "camouflage" reaches its culmination during the seventeenth and eighteenth centuries: At least in Aleppo at this time, the local copyists produced beautiful volumes, destined mainly to replace the obsolete and unintelligible rituals written in Syriac with others that still look like them in formal characteristics.

d'Aleppo nel xvii secolo. Patrimonio Culturale Arabo-Cristiano 2 (Turin: Silvio Zamorani Editore 1996), 51-53, 50-64, 110.

7. A description of this old church in Abdallah Hadjar, Historical Monuments of Aleppo (Aleppo: Automobile and Touring Club of Syria 2006), 45-49.

8. Juan Pedro Monferrer, "Avant-propos", xiii.

9. Françoise Briquel-Chatonnet, "De l'intérêt de l'étude du garshouni et des manuscrits écrits selon ce Systeme” in Geneviève Gobillot (ed.) L'Orient chrétien dans l'empire musulman. Hommage au professeur Gérard Troupeau, Studia Arabica 3 (Paris: Éditions de Paris 2005), 466. 


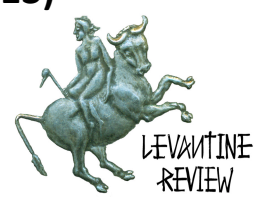

4) The language of the Karshuni texts is a semi-classic Arabic, that is, close to Arabic faseeha with occasional influences of dialectal Arabic. In works of popular origin (like hagiographies, magic, or some prayers) we can find lower levels of language. ${ }^{10}$

5) The kind of literature in Karshuni is mainly religious and is composed by Christians. There are exceptions to this rule: in the case of Aleppo, some interesting medical, magical and astrological works are preserved in two libraries of the city, specifically, the Georges and Mathilde Salem Foundation and the Maronite Mutraniyya. ${ }^{11}$

6) The practice of writing in Arabic with Syriac letters dates back to the Middle Ages. There are few examples of this kind prior to the fourteenth century, but before this period we find only short texts (titles and signatures) in Karshuni. ${ }^{12}$ The first complete books (always of Maronite origin) are substantially different because they seem to have been written by Arabized scribes and not by native Aramaic-speakers as it seems to have happened in earlier cases. ${ }^{13}$ Therefore, although the result is the same in both cases, we have to distinguish between the old examples (before the fourteenth and fifteenth centuries) and the modern texts (fifteenth to twentieth centuries,) in order to adequately explain the phenomenon of Arabic-Karshuni. In the case of these "modern texts," written, as mentioned earlier, by Maronites, there are a number of books dating back to the fifteenth century, but we cannot speak about a massive production of this kind of manuscripts until the sixteenth and seventeenth centuries. This practice extends into the next centuries, resisting the impact of the Nahda (the Arabic literary and cultural renaissance, $)^{14}$ and continuing until the first half of the twentieth century. ${ }^{15}$

All this leads us to believe that Karshuni is clearly a contrived way of writing. What is the reason for such artificiality? Why did some Arabic speakers, perfectly adapted to the dominant culture, prefer to use this forced system? On this point, one must remember that the Maronite religious hierarchy played an essential role in the introduction and

10. Monferrer, "Avant-propos", xi-xii.

11. These manuscripts are described in Del Río, Catalogue des Manuscrits de la Fondation Georges et Mathilde Salem, 57.

12. A summary of this question with bibliography, in Mengozzi, "The History of Garshuni", 300-303.

13. Georg Graf, Geschichte der christlichen arabischen Literatur (Rome/Vatican City: Biblioteca Apostolica 1944-1953), II, 102.

14. Against a common opinion that links the obsolescence of Karshuni with this cultural movement. Mengozzi, "The History of Garshuni”, 300; Monferrer, "Avant-propos”, ix. 15. The 'old practice' (that is, the occasional use of Karshuni by Syriac or bilingual speakers) is preserved in Mesopotamia (East Turkey/Iraq) and Persia until today. The 'Maronite practice' described here was introduced in the Chaldean area due probably to the Uniate influence. Briquel-Chatonnet, "De l'intérêt de l'étude du garshouni", 469; Amir Harrak, Syriac and Garshuni Inscriptions of Iraq. Recueil des inscriptions syriaques 2 (Paris: De Boccard 2010). On the other hand, the last two Karshuni Maronite manuscripts copied in Aleppo (numbers 1614 and 1615) were finished in the years 1938 and 1940 respectively: Del Río, Manuscrits en Arabe Karshuni, 145. 


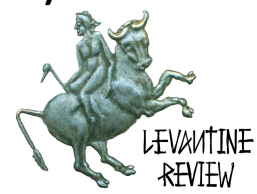

establishment of Karshuni. In fact, in the prescriptions that emanated from the Lebanese Synod of 1736, the Arabic calligraphy was strictly forbidden in all theological, liturgical, philosophical and grammatical books. ${ }^{16}$ Probably, the official adoption of Karshuni as "the Maronite Nation's writing" had already taken place through the initiative of other hierarchies such as the Archbishop of Aleppo, Germanus Farhat (d. 1732) who, with the help of his friend and copyist Butrus al-Maruni, arabized the local liturgy, preserving the Syriac form of the texts by way of Karshuni.

The reason for this choice, at least in the case of Maronites, necessarily involved the need to reaffirm their distinct identity vis-à-vis Muslims on the one hand, and other Christian sects on the other hand. With regards to the first impulse (that is, the need to preserve a distinct Maronite identity vis-à-vis Muslims,) it should be noted that, from the beginning of the Muslim domination of the Near East, the Islamic power had promoted a cultural assimilation policy, which gradually led non-Muslims to adopt typical elements of Islamic civilization. A good example of this is the patterns of social organization into "religious communities," which has been described at times as being like a mosaic. ${ }^{17}$

But perhaps the most significant and irreversible sign of cultural Islamization was the adoption of Arabic by non-Muslims, not only as daily language but also as a literary and cultural vehicle of communication. In this context, the use of Karshuni allowed Maronites to preserve their traditional attachment to Classical Syriac, which, being a symbol of their cultural and religious identity, ${ }^{18}$ had become lost to them due to the Muslims' policies of Arabization. Furthermore, Karshuni also allowed for the protection of some religious texts destined for the internal use of the community. ${ }^{19}$ In fact, in the Maronite library of Aleppo we find a good number of these books, most notably the works devoted to polemics against Islam or the philosophical, theological or historical treatises redacted with the aim of demonstrating or stressing the pre-eminence of Christianity over the other religions.

As mentioned earlier, one can find books in Karshuni dating back to the fifteenth century, copied by Maronites who were also Arabic-speakers. But a massive production

16. Joseph Féghali, Histoire du droit de l'église maronite (Paris: Letouzey et Ané 1962), vol. 1, 49; Michael Hayek, Liturgie Maronite, Histoire et Textes Eucharistiques (Paris: Mame 1964), 97; Elies Atallah, Le Synode Libanais de 1736 (Antélias/Paris: CeroLetourney et Ané 2001), vol. 2, XIII, 1. 17. The expression "mosaic society" was coined by Ira Lapidus, "The Early Evolution of Muslim Urban Society" Comparative Studies in Society and History 15 (1973), 21-50.

17. The expression "mosaic society" was coined by Ira Lapidus, "The Early Evolution of Muslim Urban Society" Comparative Studies in Society and History 15 (1973), 21-50. 18. Riccardo Contini, "The role of linguistics in Syrian society", Sylvain Auroux (ed.) History of the Language Sciences: an international handbook on the evolution of study of language from the beginnings to the present (Berlin: Walter de Gruyter 2000), 343.

19. Blau uses the same explanation to justificate the use of Hebrew letters in Medieval Judaeo-Arabic: Joshua Blau, The Emergence and Linguistic Background of Judaeo-Arabic. A Study of the Origins of Middle Arabic (Jerusalem: Ben Zvi Institute 1981), 41-42. 


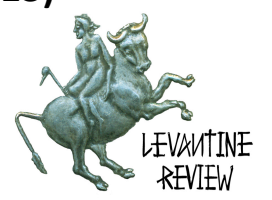

of this kind of manuscript did not begin until the sixteenth century, reaching its climax during the seventeenth and eighteenth centuries. Why did this happen at that particular time and not earlier? In my opinion, there exists a connection between the Ottoman rule of Syria and the development of Karshuni-at least among the Aleppine Maronitesbecause it is during this same period that the Maronite community began expressing the need for finding new elements with which to rebuild their own identity as a distinct collective before the Muslims and other local Christian factions.

To understand this it should be noted that after the Ottoman conquest of Syria (1516,) the Maronites of Aleppo suffered a strong "erosion of identity." This is attributable to two circumstances in particular: a) the policies vis-à-vis local Christians as applied by the new governors; and b) the "Uniatism" (that is to say, the tentative of unifying the Eastern Churches with Rome) promoted by the Holy See in the Arab-defined territories during the sixteenth century and afterwards. In this sense, it is important to remember that the main headquarters of the European Catholic missionaries were situated in Aleppo.

About the first idea, that is, the policies vis-à-vis local Christians as applied by the Ottomans, it should be remembered that the Ottoman attitudes toward the so-called "Arab Christians" have often been described by historians as being tolerant and pragmatic. In fact, such policies were even depicted as a lack of interest in the internal affairs and the doctrinal differences of Christian communities of the Arab-defined territories - that is to say, a lack of interest as long as these Christian issues did not affect the governance of the Muslim territories and the dignity of Islam. These policies were based on an old legal principle, al-kufr milla wahida ("all the unbelievers form a single nation,") ${ }^{20}$ which can be interpreted as "the Muslims should not get involved in doctrinal questions or in the life of dhimmis." 21 In practice, this indifference to the peculiarities of non-Muslims produced in return a form of communal pride and selfexaltation on the part of each individual Christian ta'ifa.

In the specific case of the Maronite Church of Aleppo, it had been the only Catholic ta'ifa of the city for centuries. ${ }^{22}$ The well-known historical Maronite fidelity to Rome and the self-conviction of being the only community belonging to the Syriac tradition to have remained true to Chalcedonian Orthodoxy, made up for the Latinization of their rites and the Arabization of their costumes. ${ }^{23}$ But the emergence of the Uniatism in Aleppo at the end of the sixteenth century fomented the emergence of new Catholic factions endowed with new strong identities thanks to the mixture of tradition, Arabization (a typical feature of the Uniate churches which was fomented by the missionaries, ${ }^{24}$ ) and

20. Muhammad al-Qurtubi, Al-Gami' li-Ahkam al-Qur'an (the Compiler for the Judgments of the Quran) 20 vols. (Riad: Dar 'Alim al-Kutub 1423/2003), II, 93.

21. Bruce Masters, Christians and Jews, 64, 84, 106.

22. Ghantuz, I Maroniti di Aleppo, 51-53, 50-64, 110.

23. Mati Moosa, The Maronites in History (Piscataway NJ: Gorgias Press 2005), 217.

24. In fact, Arabic became the language of the Uniates in the Middle East. Robert Haddad, Syrian Christians in a Muslim Society. An Interpretation (Princeton: Princeton Univ. Press 


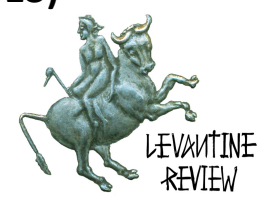

obedience to the Holy See. It is well known how these new Catholics soon cast doubt on the purity of the Latinized rituals of the Aleppine Maronites and on their perpetual orthodoxy. ${ }^{25}$

It is with this background in mind that one must assess the Maronites, their search for a myth of origin and the legendary lineage of their church, and their vehement rejection of an ascribed Arab identity (an "article of faith" still widely attested to, even today, among the Maronites of Lebanon.) ${ }^{26}$ The use of Karshuni should be framed in this context.

1970), 53-54; Bernard Heyberger, Les chrétiens du Proche-Orient au temps de la réforme catholique (Syrie, Liban, Palestine XVI-XVII s.) (Rome: École Française 1994), 344-345; Bruce Masters, Christians and Jews, 87-88, 95-87.

25. Mati Moosa, The Maronites in History, 217. From this time comes the controversy on the so-called "perpetual orthodoxy of Maronites" which will go on until the twentieth century. Pierre Dib, Histoire de l'Église Maronite (Beirouth: La Sagesse 1962), 38, 43. 26. The isolation of this community facilitated the creation of a legendary past which links Maronites with Phoenicians, Mardaites, Nabataeans or even Iranians. Mati Moosa, The Maronites in History, 174-194; Jean-Pierre Valognes, Vie et mort des Chrétiens d'Orient. Des origines à nous jours (Paris: Fayard 1994), 368-369, 381; Project MANALEP/3 (FFI2011-25460/FILO) 


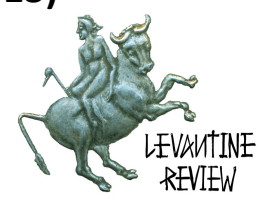

\section{BIBLIOGRAPHY}

Atallah, Elies, Le Synode Libanais de 1736, Antélias/Paris: Cero-Letourney et Ané 2001.

Blau, Joshua, The Emergence and Linguistic Background of Judaeo-Arabic. A Study of the Origins of Middle Arabic, Jerusalem: Ben Zvi Institute 1981.

Briquel-Chatonnet, Françoise, "De l'intérêt de l'étude du garshouni et des manuscrits écrits selon ce Systeme" in Geneviève Gobillot (ed.) L'Orient chrétien dans l'empire musulman. Hommage au professeur Gérard Troupeau, Studia Arabica 3, Paris: Éditions de Paris 2005, 463-475.

Contini, Riccardo, "The role of linguistics in Syrian society", Sylvain Auroux (ed.) History of the Language Sciences: an international handbook on the evolution of study of language from the beginnings to the present, Berlin: Walter de Gruyter 2000, 341344.

Dib, Pierre, Histoire de l'Église Maronite, Beirut: La Sagesse 1962.

Féghali, Joseph, Histoire du droit de l'église maronite, Paris: Letouzey et Ané 1962.

Ghantuz, Mariam de, I maroniti d'Aleppo nel xvii secolo. Patrimonio Culturale AraboCristiano 2, Turin: Silvio Zamorani Editore 1996.

Graf, Georg, Geschichte der christlichen arabischen Literatur, Rome/Vatican City: Biblioteca Apostolica 1944-1953.

Haddad, Robert, Syrian Christians in a Muslim Society. An Interpretation, Princeton: Princeton Univ. Press 1970.

Hadjar, Abdallah, Historical Monuments of Aleppo, Aleppo: Automobile and Touring Club of Syria 2006.

Harrak, Amir, Syriac and Garshuni Inscriptions of Iraq. Recueil des inscriptions syriaques 2, Paris: De Boccard 2010.

Hayek, Michael, Liturgie Maronite, Histoire et Textes Eucharistiques, Paris: Mame 1964.

Heyberger, Bernard Les chrétiens du Proche-Orient au temps de la réforme catholique, (Syrie, Liban, Palestine XVI-XVII s.), Rome: École Française 1994.

Lapidus, Ira, "The Early Evolution of Muslim Urban Society" Comparative Studies in Society and History 15 (1973), 21-50. 


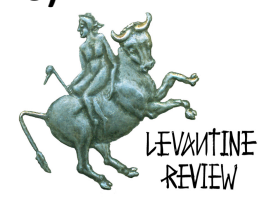

Masters, Bruce, Christians and Jews in the Ottoman Arabic Word: The Roots of Sectarism, Cambridge: Cambridge Univ. Press 2001.

Mengozzi, Alessandro, "The History of Garshuni as a Writing System: Evidence from the Rabbula Codex" in Frederick Mario Fales and Julia Francesca Grassi (eds.), CAMSEMUD 2007, Proceedings of the 13th Italian Meeting of Afro-Asiatic Linguistics, Padova: SARGON Editrice, 297-304.

Moosa, Mati, The Maronites in History, Piscataway NJ: Gorgias Press 2005.

Qurtubi, Muhammad al-, Al-Gami' li-Ahkam al-Qur'an (the Compiler for the Judgments of the Quran) 20 vols., Riad: Dar Alim al-Kutub 1423/2003.

Río, Francisco del, Catalogue des Manuscrits de la Fondation Georges et Mathilde Salem (Alep, Syrie), Wiesbaden: Reichert Verlag 2008.

Río, Francisco del, Manuscrits syriaques conservés dans la bibliothèque des Maronites d'Alep (Syrie), Piscataway NJ: Gorgias 2008

Río, Francisco del, Manuscrits en Arabe Karšuni conservés dans la bibliothèque des Maronites d'Alep, Syrie, Piscataway NJ: Gorgias 2010.

Salibi, Kemal Suleyman, Maronite historians of medieval Lebanon, Beirut: American University 1959.

Valognes, Jean-Pierre, Vie et mort des Chrétiens d'Orient. Des origines à nous jours, Paris: Fayard 1994.

* Francisco del Río Sánchez is Associate Professor in the Department of Semitic Languages at the University of Barcelona (Spain.) He has worked in Aleppo (Syria) for the past fourteen years, directing a research project cataloguing Syriac and Arabic manuscripts preserved in family collections and private libraries throughout Aleppo. Dr. del Río Sánchez has written extensively in the field of Semitics, Arabic, and Aramaic Studies. 